\title{
New Hopes in Retinoblastoma Treatment
}

\author{
Semra A. TURHAN, Osman CEKIC
}

Marmara University School of Medicine, Department of Ophtalmology, Istanbul, TURKEY

\begin{abstract}
Survival rates of retinoblastoma have increased dramatically during the last decade. The current major treatment modalities for retinoblastoma include enucleation, intravenous chemoreduction, external beam therapy, focal treatments (such as brachytherapy and transpupillary thermotherapy), subconjunctival chemotherapy and selective ophthalmic artery chemotherapy. Although current treatment modalities have improved survival rates as well as eye salvage, new treatment modalities are expected to arise in the near future, since above mentioned non-targeted treatments have extensive side effects. Recent advances in genetic analysis of retinoblastoma 1 (RB1) mutations and pathways leading to retinoblastoma may provide vital information for the development of new targeted therapies which are less toxic.
\end{abstract}

Keywords: Genetics, Retinoblastoma, RB1 mutation, Targeted treatments

\section{ÖZET}

Retinoblastom Tedavisinde Yeni Umutlar

Son on yılda retinoblastomda sağ kalım oranları dramatik olarak artmıştır. Enükleasyon, intravenöz kemoredüksiyon, dışsal ışın radyoterapi, fokal tedaviler (brakiterapi ve transpupiller termoterapi gibi), subkonjonktival kemoterapi, selektif oftalmik arter kemoterapi retinoblastomda kullanılan önemli tedavi modaliteleridir. Yeni tedavi seçenekleri göz küresinin kurtarıması ve sağkalım oranlarında iyileşme sağlamasına rağmen, özgül olmayan kemoterapi ajanlarının yaygın yan etkileri nedeniyle gelecekte yeni tedavi modalitelerine intiyaç duyulmaktadır. Retinablastom 1RB1 mutasyonlarının gen analizi ve retinoblastom oluşumunu sağlayan yolaklardaki son gelişmeler; daha az toksisitesi olan hedeflenmiş terapilerin gelişiminde önemli bilgiler sağlayacaktır.

Anahtar Kelimeler: Genetik, Retinoblastoma, RB1 mutasyonu, Hedeflenmiş tedaviler 


\section{INTRODUCTION}

Retinoblastoma (RB) is the most common primary intraocular malignancy of childhood. The management of RB is challenging. Current treatments for intraocular RB include enucleation, systemic chemotherapy, external beam radiation therapy (EBRT), focal treatments, intra-arterial or subconjunctival chemotherapy. ${ }^{1}$ The results of treatment depend on the stage of the disease. Early diagnosis and intensive treatment have been adopted in developed countries. Survival rates of RB exceeds $90-95 \%$ in $\mathrm{USA}^{2}$ but the survival rate changes country by country according to availability of medical care. Early diagnosis and intervention is crucial for successful treatment of RB. The current important issues in RB research are the targeted approaches which are more effective and less toxic. This article reviews the new targeted treatment modalities for RB.

\section{GENETICS}

The disease is associated with $\mathrm{RB}$ gene which is a tumor suppressor gene. RB results from loss of retinoblastoma 1 gene (RB 1) or inactivation of both alleles. In the early 1970s, Knudson theorized the 'two hit' model. In this model, loss of both copies of the $\mathrm{RB}$ gene is required for the development of $\mathrm{RB}$ and it occurs in two forms: the hereditary and non-hereditary forms. Although it requires loss of both alleles, one allele is mutated in the germline and other mutation occurs somatically in the developing retina in hereditary form. In non-hereditary form, both mutations occur somatically. However, some authors recently reported that genomic instability and aneuploidy have impact on initiation of tumor formation..$^{3-5} \mathrm{RB}$ and retinoma cells have common genomic changes. ${ }^{6,7}$ They showed that retinomas are homozygous null for RB1 and lack expression of retinoblastoma protein product of RB1 (pRB). ${ }^{5}$ Retinomas also have a low level of genomic copy number changes in tumor suppressor genes and oncogenes. However, RB tissue showed high levels of genomic copy number changes and a low level of senescence proteins. In addition, retinomas are rarely stable because loss of pRB causes genomic instability, leading to proliferative RB tumors.

In spite of aneuploidy and genomic instability, the importance of mutational events other than RB1 is accepted by authors. Mutations in the RB gene show a high degree of mutational heterogeneity. Valverde et al. ${ }^{8}$ reported that 932 mutations in $\mathrm{RB}$ gene are available in a searchable database. These mutations have been consisted of inactivated pRB by deletions, nonsense mutations and RB1 gene mutations which mainly include twelve nonsense, two missense and three splicing mutations. ${ }^{8}$

The authors hypothesized that the P13K/AKT/mTOR (insulin signaling) pathway may show dysregulation and they used microarray analysis for gene expression analysis of RB. ${ }^{9}$ This hypothesis was confirmed by semi-quantitative RT-PCR for related genes. The inhibitors of this pathway could be another option for the treatment of RB.

All these data support that biallelic inactivation of the RB1 gene is important for formation of retinoma and RB tumors, but additional genetic mutations are acquired for progression to the malignant state.

The genetic events have roles in RB tumorigenesis. Genetic alterations are common in RB tumors, including gains at chromosomal loci 1q32.1 (MDM+ gene), 6p22 (E2F3 and DEK) and 2p24 (MYCN) and losses at $16 \mathrm{q} 22 .{ }^{10} \mathrm{pRB}$, acts primarily as a regulator of gene expression. These processes include cell proliferation, senescence, apoptosis, differentiation, and chromatin remodeling. ${ }^{11} \mathrm{pRB}$ also has important roles in the fate determination, differentiation, survival, and migration of developing neurons. ${ }^{12} \mathrm{RB}$ family proteins (pRB1/105, p107, pRB2/p130, referred to as pocket proteins) interact with E2F transcription factors to fulfill the functions. ${ }^{13}$ This interaction prevents transcription of genes required for DNA synthesis and effectively arrests the cell cycle at the G1/S interface in the non-phosphorylated state. Phosphorylation of pRB by cyclin-dependent kinases results in the release of E2F to provide progression of the cell cycle. ${ }^{14-16}$

Normal pRB binds to and inhibits the E2F target genes, by preventing the binding of transcriptional co-activators, and through recruitment of histone deactylase 1 (HDAC1), ATPases, and DNA methyltransferases to the promoter of target genes which are responsible for cell progression. ${ }^{17}$ The E2F target gene MAD2 plays a role in encoding a mitotic spindle check point protein and deregulation of this protein promotes aneuploidy and tumor genesis in transgenic mice. ${ }^{18}$ Overexpression of MAD2 has a mechanism in the pathogenesis of many tumors, including RB. ${ }^{19}$ Chromatin condensation, cohesion, and stability by promoting the centromeric localization of the CAP- 


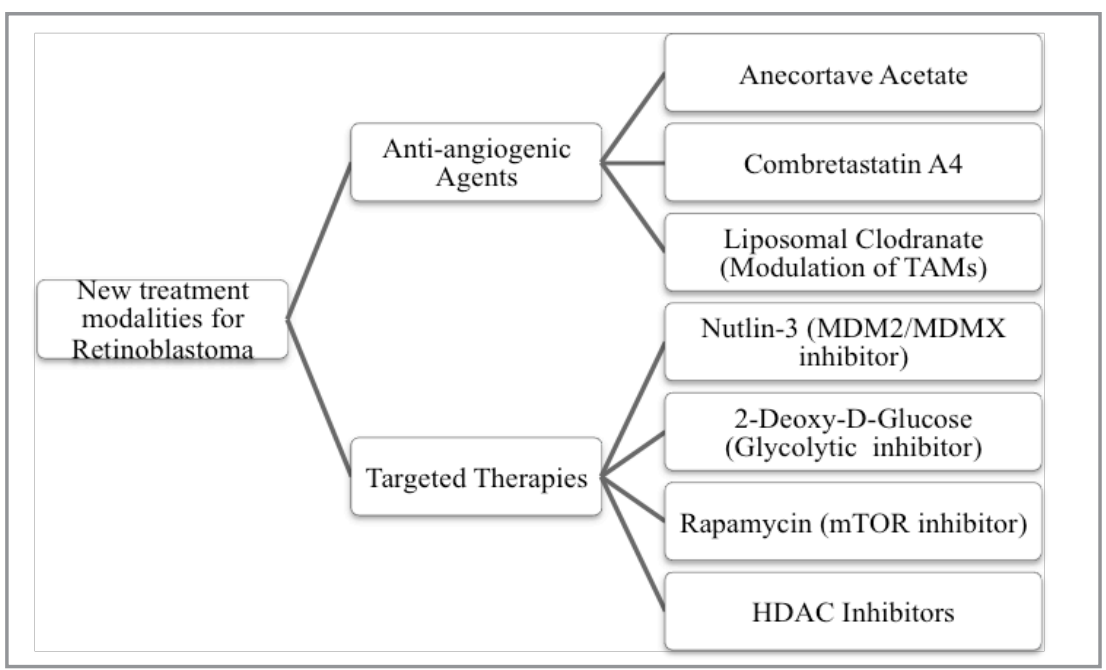

Figure 1. New treatment modalities for retinoblastoma

D3/condensing II protein complex are also regulated by $\mathrm{pRB}{ }^{20}$

Although the development and progression of RB is not directly associated with $\mathrm{p} 53$ gene mutations, recent studies have shown that inactivation of the p53 pathway is also related with RB. ${ }^{21}$ MDM2 and MDM4 are two oncogenes associated with $\mathrm{p} 53$ regulation. Their amplification and polymorphism have been associated with RB development. ${ }^{21}$ p53 is activated after loss of pRB during retinogenesis and p53-mediated apoptosis is triggered in RB-deficient cells. ${ }^{22}$ Increased expression of MDM4 protein plays a role in tumor progression. Its mechanism is to suppress p53 response in RB1-deficient retinal cells and also MDM2/MDMX-p53 pathways must be inactivated for tumor progression. They suggested that MDMX is a specific chemotherapeutic target for treating RB. ${ }^{21}$

\section{NEW TREATMENTS DERIVED FROM ANAL- YSES OF MOLECULAR PATHWAY}

One of the important issues driving research in retinoblastoma is to identify targets of inactivated $\mathrm{pRB}$ and design targeted therapies. Despite the difficulty in generating accurate murine models of RB, recently mouse models showed that conditional deletion of RB1 on a p53-deficient, p107-deficient or p130-deficient genetic background gives rise to RB tumors that resemble the human disease. ${ }^{22-23}$ All new treatment modalities are listed in Figure 1.

\section{NUTLIN-3}

Identification of MDM2/MDMX, a p53 inhibitor, has led to development of a potential targeted therapy using Nutlin-3. ${ }^{24-26,28}$ Nutlin-3 is a small-molecule inhibitor of the MDM2/MDMX-p53 pathway, which promotes the apoptosis pathway. Nutlin-3 can be used in combination with topotecan, a p53 inducer. Topotecan's pharmacologic effects have been studied in LHBetaTag murine model and subconjunctival administration of topotecan in fibrin sealant provided a clinical effect for 3 weeks after treatment. ${ }^{21}$ Treatment provided a bilateral reduction of tumor burden without a significant difference between treated and untreated eyes, suggesting that the drug was delivered predominantly through the hematogenous route. The combination Nutlin-3 and topotecan synergistically disrupt RB cells in vitro and promotes an 82-fold reduction in tumor burden following the subconjunctival injection in mouse model..$^{22,28}$ No side effect was reported in the animal models. Nutlin-3 is currently in phase 1 clinical trial for treatment of RB and its effects will require further investigation in the near future. ${ }^{29}$

\section{COMBRETASTATIN A4 AND ANECORTAVE ACETATE}

The effects of vascular targeting therapy has been studied in LHBetaTag murine model. Vascular targeting agents have an effect in decreasing tumor vasculature with subsequent enhancement in tumor control. Conventional therapies (focal treatment, external beam radiation) and the vascular targeting 
agents (combretastatin A4 and anecortave acetate) induced apoptotic cell death with minimal necrosis. ${ }^{30}$ Histopathologic analysis showed that external beam radiation and focal carboplatin treatment had effect in 1 week after treatment but the vascular targeting treatment had effect after only 1 day only. They suggested that this differential apoptosis time can have information in combined therapies for RB treatment.

\section{2-DEOXY-D-GLUCOSE (2-DG)}

Other novel agents have also developed murine models. 2-Deoxy-D-Glucose (2-DG) can be used as an adjuvant agent for treatment of murine RB. ${ }^{31}$ 2-DG effectively reduces human lung tumor and bone tumor burden when combined with standard chemotherapeutic drugs. 2-DG is currently in phase 1 clinical trial for treatment of lung, breast, and bone cancers. ${ }^{32}$ They hypothesized that in advanced disease, the tumor has hypoxic cells and 2-DG can be used for this hypoxic portions of the tumor. ${ }^{31}$

\section{ANECORTAVE ACETATE AND LIPOSOMAL CLODRONATE}

The tumor microenvironment is also important for tumor genesis. Tumor-associated macrophages (TAMs) and matrix metalloproteinases (MMPs) have been associated with tumor genesis. MMPs have important roles, which are angiogenesis, tumor growth and metastasis. Anecortave acetate reduced the expression of MMPs in LHBetaTag murine tumors and resulted in a decrease in tumor burden. ${ }^{33}$ TAMs have been associated with increased levels of MMPs and mature vessels in retinoblastoma models. Similarly, the TAMs were present during early disease and the density of these macrophages steadily increased with tumor progression. ${ }^{34}$ Subconjunctival liposomal clodronate provided the depletion of intraocular macrophages. After depletion of macrophages, MMPs expression decreased and tumor control improved but modulation of the total TAMs population did not reduce tumor. ${ }^{34}$

Combined with vascular targeting therapies that increase hypoxia, glycolytic inhibitors and anti-angiogenic agents may be used synergistically for a greater reduction in tumor burden..$^{35}$ Combination of 2-DG and Anecortave Acetate provided advanced tumor control and reduction in tumor burden compared to 2-DG alone. ${ }^{36}$

\section{RAPAMYCIN}

The PI3K/Akt/mTOR pathway was recently demonstrated to be a potentially important dysregulated pathway in the genomic expression of human RB. ${ }^{9}$ This pathway is dependent on oxygen. Treatment with the mTOR inhibitor, rapamycin, may provide destruction of chemo-resistant hypoxic cell population in LHBetaTag retinal tumors. ${ }^{37}$

\section{HDAC INHIBITORS (HDACi)}

Another option of targeted therapies currently in phase 1 clinical trials for $\mathrm{RB}$ is HDAC inhibitors (HDACi). pRB binds to HDAC and promotes silencing of transcription. When E2F1 activity is increased, proapoptotic factors are overexpressed and subsequently cells will be sensitive to HDACi. ${ }^{38}$ They suggested that HDACIs will be more effective in tumors with high E2F1 activity. HDACi reduced cell survival in human RB cell and reduced tumor burden. ${ }^{39}$

\section{CONCLUSION}

If the origin of RB cell was exactly known, it would shed light on new treatments for the initial precursor cell. Some authors reported that RB tumors express markers specific to cone precursor cells, including RXR $\gamma$ and TR $32 .^{40}$ They also demonstrated that human cone precursors prominently express MDM2 and N-Myc, that RB cells require both of these proteins for proliferation and survival. The presence of a cone precursor to RB tumors might suggest that these tumors would be more concentrated in the fovea, the portion of the retina with the highest cone density; however, it was not observed clinically.41 Further studies will likely bring answers to many of these questions.

In conclusion, understanding of the genetic basis and the mechanism of underlying malignant transformation of retinal and other cell types will lead to the development of new therapies. This will provide a less toxic but more effective treatment.

\section{REFERENCES}

1. Shields CL, Shields JA. Basic understanding of current classification and management of retinoblastoma. Curr Opin Ophthalmol 17: 228-234, 2006.

2. Broaddus E, Topham A, Singh AD. Survival with retinoblastoma in USA: 1975-2004. Br J Ophthalmol 93: 24-27, 2009. 
3. Mastrangelo D, De Francesco S, Di Leonardo A, et al. Retinoblastoma epidemiology: does the evidence matter? Eur J Cancer 43: 1596-1603, 2007.

4. Mastrangelo D, De Francesco S, Di Leonardo A, et al. Does the evidence matter in medicine? The retinoblastoma paradig. Int J Cancer 121: 2501-2505, 2007.

5. Dimaras H, Khetan V, Halliday W, et al. Loss of RB1 induces nonproliferative retinoma: increasing genomic instability correlates with progression to retinoblastoma. Hum Mol Genet 17: 1363-1372, 2008.

6. Sampieri K, Mencarelli MA, Epistolato MC, et al. Genomic diffences between retinoma and retinoblastoma. Acta Oncol 47: 1483-1492, 2008

7. Sampieri K, Amenduni M, Papa FT, et al. Array comparative genomic hybridization in retinoma and retinoblastoma tissues. Cancer Sci 100: 465-471, 2009.

8. Valverde JR, Alonso J, Palacios I, et al. RB1 gene mutations update, a meta-analysis based on 932 reported mutations available in a searchable database. BMC Genet 6: 53, 2005.

9. Chakraborty S, Khare S, Dorairaj SK, et al. Identification of genes associated with tumorigenesis of retinoblastoma by microarray analysis. Genomics 90: 344-353, 2007.

10. Nichols KE, Walther S, Chao E, et al. Recent advances in retinoblastoma genetic research. Curr Opin Ophthalmol 20: 351-355, 2009

11. Burkhart DL, Sage J. Cellular mechanism of tumour suppression by the retinoblastoma gene. Nat Rev Cancer. 8: 671682, 2008.

12. Ferguson $\mathrm{KL}$, Slack RS. The pathway in neurogenesis. Neuroreport 12: A55-62, 2001

13. Whyatt DFG, Grosveld F. Cell-nonautonomous function of the retinoblastoma tumor supressor protein: New interpretations of old phenotypes. EMBO Rep 3: 130-135, 2002.

14. Harper JW, Adami GR, Wei N, et al. The p21 Cdk-interacting protein Cip1 is a potent inhibitor of G1 cyclin-dependent kinases. Cell 75: 805-816, 1993.

15. Xiong $\mathrm{Y}$, Hannon GJ, Zhang $\mathrm{H}$, et al. p21 is a universal inhibitor of cyclin kinases. Nature 366: 701-704, 1993.

16. Gartel AL, Serfas MS, Tyner AL. p21-negative regulator of the cell cycle. Proc Soc Exp Biol Med 213: 138-149, 1996.

17. Khetan V, Gupta A, Gopal L. Retinoblastoma: Recent trends A mini review based on published literature. Oman J Ophthalmol 4: 108-115, 2011

18. Sotillo R, Hernando E, Díaz-Rodríguez E, et al. Mad2 overexpression promotes aneuploidy and tumorigenesis in mice. Cancer Cell 11: 9-23, 2007.

19. Hernando E, Nahlé Z, Juan G, et al. RB inactivation promotes genomic instability by uncoupling cell cycle progression from mitotic control. Nature 430: 797-802, 2004.

20. Longworth MS, Herr A, Ji JY, et al. RBF1 promotes chromatin condensation through a conserved interaction with Condensin II protein dCAP-D3. Genes Dev 22: 1011-1024, 2008.
21. Tsui JY, Dalgard C, Van Quill KR, et al. Subconjunctival topotecan in fibrin sealant in the treatment of transgenic murine retinoblastoma. Invest Ophthalmol Vis Sci 49: 490-496, 2008.

22. Laurie NA, Donovon SL, Shih CS, et al. Inactivation of the p53 pathway in retinoblastoma. Nature 444: 61-66, 2006.

23. MacPherson $D$. Insights from mouse models into human retinoblastoma. Cell Div 3: 9, 2008.

24. Du W, Wu J, Walsh EM et al. Nutlin-3 affects expression and function of retinoblastoma protein: role of retinoblastoma protein in cellular response to nutlin-3. J Biol Chem 284: 26315 26321, 2009.

25. MacPherson D, Dyer MA. Retinoblastoma: from the two-hit hypothesis to targeted chemotherapy. Cancer Res 67: 7547 7550, 2007

26. Secchiero P, Bosco R, Celeghini C, et al. Recent advances in the therapeutic perspectives of Nutlin-3. Curr Pharm Des. 17: 569-577, 2011.

27. Drakos E, Atsaves V, Li J, et al. Stabilization and activation of p53 downregulates mTOR signaling through AMPK in mantle cell lymphoma. Leukemia 23: 784-790, 2009.

28. Brennan RC, Federico S, Bradley C, et al. Targeting the p53 pathway in retinoblastoma with subconjunctival Nutlin-3a. Cancer Res. 71: 4205-4213, 2011.

29. Secchiero P, Bosco R, Cleghini C, et al. Recent advances in the therapeutic perspectives of nutlin-3. Curr Pharm De 17: 569-577, 2011.

30. Jockovich ME, Suarez F, Alegret A, et al. Mechanism of retinoblastoma tumor cell death after focal chemotherapy, radiation, and vascular targeting therapy in a mouse model. Invest Ophthalmol Vis Sci 48: 5371-5376, 2007.

31. Boutrid H, Jockovich ME, Murray $\mathrm{T}$, et al. Targeting hypoxia, a novel treatment for advanced retinoblastoma. Invest Ophthalmol Vis Sci 49: 2799-2805, 2008.

32. Lampidis TJ, Kurtoglu M, Maher JC, et al. Efficacy of 2-halogen substituted D-glucose analogs in blocking glycolysis and killing 'hypoxic tumor cells'. Cancer Chemother Pharmacol 58: 725-734, 2006.

33. Bajenaru L, Pina Y, Murray T, et al. Gelatinase expression in Retinoblastoma: Modulation of LHBetaTag retinal tumor development by Anecortave Acetate. Invest Ophthalmol Vis Sci 51: 2860-2864, 2010.

34. Pina $\mathrm{Y}$, Boutrid $\mathrm{H}$, Murray $\mathrm{T}$, et al. Impact of Tumor-Associated Macrophages in LHBETATAG on retinal tumor progression: relation to macrophage sub-type. Invest Ophthalmol Vis Sci 51: 2671-2677, 2010.

35. Houston SK, Murray TG, Wolfe SQ, et al. Current update on Retinoblastoma. Int Ophthalmol Clin 51:77-91, 2011.

36. Houston SK, Pina Y, Murray TG, et al. Novel retinoblastoma treatment avoids chemotherapy: the effect of optimally timed combination therapy with angiogenic and glycolytic inhibitors LHBetaTag retinoblastoma tumors. Clin Ophthalmol 5:129137, 2011 
International Journal of Hematology and Oncology

37. Pina Y, Decatur C, Murray TG, et al. Advanced retinoblastoma treatment: targeting hypoxia by inhibition of the mammalian target of rapamycin (mTOR) in LHBetaTag retinal tumors. Clin Ophthalmol 5: 337-343, 2011.

38. Zhao Y, Tan J, Zhuang L, et al. Inhibitos of histone deacetylases target the RB-E2F1 pathway for apoptosis induction through activation of proapoptotic protein. Bim Proc Natl Acad Sci USA 102: 16090-16095, 2005.

39. Dalgard CL, van Quill KR, O'Brien JM, et al. Evaluation of the in vitro and in vivo anti-tumor activity of histone deacetylase inhibitors for the therapy of retinoblastoma. Clin Cancer Res 14: 3113-3123, 2008.

40. Xu XL, Fang Y, Lee TC, et al. Retinoblastoma has properties of a cone precursor tumor and depends upon cone-specific MDM2 signaling. Cell 12: 1018-1031, 2009.

41. Sachdeva UM, O'Brien JM. Understanding pRB: toward the necessary development of targeted treatments for retinoblastoma. J Clin Invest 122: 425-434, 2012.

\section{Correspondence}

Dr. Semra AKKAYA TURHAN

Marmara Üniversitesi Tıp Fakültesi

Göz Hastalıkları Anabilim Dalı

Pendik

ISTANBUL / TURKEY

Tel: (+90.216) 6254545

e-mail: semraakkaya85@hotmail.com 